\title{
EDIÇÃo INSPIRADORA
}

Muniz, Fernando (org.). As artes do entusiasmo. A inspiração da Grécia antiga à contemporaneidade. [Coleção Estudos Clássicos. Volume ], Rio de Janeiro: FAPERJ, 7Letras, 2011, 112 pp.

Uma embriaguez, me faz, arauto, Sem medo ao jogo do mar alto,

Para erguer, de pé, este brinde "Brinde", Stéphane Mallarmé

Embriaguez e engajamento (“Une ivresse belle m'engage”) raramente se associam talvez por isso, quando a associação acontece a imagem que gera pode parecer imprevisível, fragmentada, inaudita com uma exceção discutida longamente desde a antiguidade: a do poeta ou artista inspirado. O poeta, para ser poeta, deve estar embriagado, deve ter bebido o elixir da musa. Inclusive, no seio da própria modernidade - que por todos os meios tentou afastar a arte de qualquer relação com o incompreensível - Mallarmé retoma, em "Brinde", o gesto da inspiração, levanta a taça para beber, colocar o elemento estonteante dentro de si: e entusiasmar-se. Esse gesto complexo, pelo qual se interpenetram o eu e o outro, o poeta e os deuses, o dentro e o fora, sob diversos pontos de vistas e através de diversos objetos, é o foco da instigante coletânea organizada pelo professor de filosofia da Universidade Federal Fluminense, Fernando Muniz.

A coletânea vem anunciar uma coleção promissora e necessária, a Coleção Estudos Clássicos projetada pelo Pólo de Estudos Clássicos do Rio de Janeiro, que reúne diversos laboratórios e programas de estudos em Filosofia e Letras, e que conta com o apoio da FAPERJ, a Fundação Biblioteca Nacional e a Sociedade Brasileira de Estudos Clássicos. Ao mesmo tempo, a coleção poderá permitir aos estudantes e pesquisadores de áreas afins à filosofia o acesso a uma genealogia - que passa pelas diversas fases do que se entende por clássico - de questões filosóficas e conceituais contemporâneas, mas não novas.

$\mathrm{Na}$ apresentação, Fernando Muniz deixa clara a importância da escolha das teorias e as artes do entusiasmo para o volume inaugural: se, por um lado, "o entusiasmo é, sem dúvida, o mais antigo e resistente modelo explicativo da criação poética” (p.13), por outro, esse modelo, tem sido o mais negado e discutido pelas teorias modernas - ou seja, dos últimos dois séculos - sobre a literatura. O termo entusiasmo, portanto, é logo no começo apresentado e desdobrado por Muniz com a ajuda da etimologia, mesmo que ela não seja 
estável: éntheos qualificava a quem tem um deus dentro, ou que foi incorporado por ele. Inspiratio é, lemos, o termo latino que ressaltou um aspecto específico do termo grego: a relação do entusiasmo com o sopro, o sopro divino e ao mesmo tempo interior presente na respiração do inspirado. Nesse sentido, continua Muniz, "do caráter público e performático do enthousiasmós grego até a inspiração privada do 'gênio' romântico, muitos foram os desvios no caminho que fizeram com que os dois termos ora se aproximassem ora se afastassem" (p.14); e anuncia desse modo o que, no final das contas, acharemos nos interessantes e diversos cinco ensaios que completam o volume.

O primeiro, do professor da UFMG Jacyntho Lins Brandão, aborda o trânsito da noção de entusiasmo, na antiguidade grega, entre uma experiência religiosa e uma artística. Partindo da reflexão platônica do Íon, onde o poeta inspirado se acha “fora de si", Brandão mostra em que medida a musa vai se deslocando e perdendo a sua importância na origem criativa, passando a serem centrais as capacidades de Homero como criador/narrador e, por extensão, mostrando a centralidade do literato moderno como construtor.

O próprio organizador Fernando Muniz, no segundo ensaio, aborda as leituras desse mesmo texto matriz em torno do entusiasmo, o Íon de Platão, feitas por Shelley e Goethe. Leituras antagônicas mas ambas feitas no coração da formação do movimento romântico alemão. Partindo da constatação da contraposição, Muniz ensaia a própria leitura, seguindo o encadeamento metafórico e magnético do diálogo platônico, resultando em uma leitura temperada que afasta Sócrates da acusação de apresentar posicionamentos apriorísticos, seja a favor ou contra a poesia.

Já no terceiro ensaio, o também professor da Universidade Federal Fluminense e editor da excelente revista virtual Viso. Cadernos de estética aplicada, Vladimir Vieira, parte da apresentação de dois espectros de aplicação da noção de entusiasmo na Alemanha do século XVIII: por um lado, o entusiasmo estaria relacionado com a inspiração e a criação artística; por outro, na sua derivação Schwärmen - literalmente "enxame" - referiria ao agrupamento de indivíduos: entusiasmados que realizam ações coletivas, mesmo que de forma desordenada, derivando inclusive no fanatismo. A diferença que existe entre uma idéia e outra, apesar de ter sido historicamente confundida seria, segundo Vieira desenvolve ao longo do artigo, substancial para compreender as reflexões que Kant dedica ao tema do entusiasmo em algumas passagens, especialmente, de Crítica da faculdade do juíro.

Se o texto de Vieira pode ser pensado como um solo filosófico para que os pesquisadores das artes abordem a questão do entusiasmo, o ensaio seguinte, do professor de Teoria Literária da Universidade do Estado de Rio de Janeiro Júlio França vai explicitar 
e explicar a moderna - e já tradicional - rejeição das teorias do entusiasmo, por parte da teoria literária (especialmente a acadêmica, principal herdeira das visões formalistas). A contraposição não surpreende: as do entusiasmo são teorias que se abismam sobre um fator do trabalho artístico que insiste em permanecer não dito, não explicável, irredutível. As Teorias da Literatura acadêmicas, pelo contrário, QUE colocam o peso ora na materialidade do texto ou ora na sua recepção, tiveram que se negar a pensar a criação. Para realizar o pertinente movimento de reconduzir do pensamento sobre o entusiasmo para o pensamento sobre a literatura, França se arrisca ao tomar como fortes pilares da sua argumentação as declarações dos próprios artistas sobre a sua produção. Artistas de fama formalista - como João Cabral - mas que não deixariam de reconhecer algo de não explicável, uma disposição peculiar na hora de escrever.

Como se levantasse a luva da reflexão de França, o poeta Antônio Cícero fíca encarregado do último ensaio. Porém, o poeta não tenta dar testemunho da própria produção em termos entusiasmados ou não. Cícero encara neste "As Musas e a liberdade poética" uma árdua e belíssima odisséia pela Odisséia de Homero para tentar sustentar a possibilidade de pensar o poema a partir da sua origem divina e, mesmo assim, apontar de que forma essa mesma origem divina outorga ao poeta liberdade e autonomia em relação ao político, ao ético ou à verdade. "Sua única consideração é precisamente estética" (p.90). Autonomia e importância estética que, anunciadas na antiguidade, dirá Cícero, ganham todos os espaços na era moderna.

Já no final, os leitores entusiasmados com o assunto devem agradecer uma estudada bibliografia (complementar das referências nas notas de rodapé) que, ao mesmo tempo, levando em conta as pouquíssimas referências a textos publicados a partir de 2000, testemunham a ausência de pesquisas sobre o tema realizadas nos últimos anos.

Mas não termina ai: vale ainda destacar o "brinde" que aparece nas últimas quatro páginas. Vladimir Garcia traduz o "Platão como partícipe de uma revelação cristã", de Goethe, onde o alemão reflete, justamente, dando as bases da concepção romântica e moderna de inspiração. Goethe aproxima anacronicamente a idéia de revelação cristã ao movimento que realiza Platão - ou Sócrates - ao humilhar Íon quem, ao longo do diálogo, de um rapsodo talentoso e esforçado, passa a ter que "reconhecer-se como um homem que foi entusiasmado [begeistert] por meio de uma imediata inspiração divina” (p.110). Goethe, no furibundo texto, mostra que Sócrates, fazendo uso de artimanhas discursivas e se mostrando como único detentor possível de sabedoria, acaba deixando a Íon a cruel escolha entre se admitir um idiota ou um homem tocado pela revelação divina. Ou seja, 
entre um simples mentiroso que diz saber sobre condução de exércitos, marcenaria e medicina quando apenas imita, ou um lírico inspirado, mais próximo ainda da verdade que os próprios filósofos. Goethe, fiel ao seu tempo, afasta a inspiração da divindade ou da idéia de revelação vinda de fora, para colocar o peso nas paixões do artista, no gênio, das quais um poeta é capaz. "Já passou o tempo em que as sibilas profetizavam sobre a terra" (p.112).

Voltemos, para fechar, a Mallarmé. "Brinde" pode ser pensado como um sintoma ao mesmo tempo do ápice da modernidade e da sua crise, da centralização do homem e sua interioridade e o esfacelamento das certezas da expressão de um eu, da importância da inspiração e a sua impossibilidade de continuar localizando-se no interior do sujeito. Do mesmo modo, podemos pensar que a vontade de alguns pesquisadores e intelectuais de pensar o entusiasmo, ou seja, de pensar ateia e novamente em deus, vem apontar que a inspiração não pode continuar ficando de fora, que o entusiasmo é parte central dos problemas da arte contemporânea, da crítica e de nossa cultura.

Um brinde a uma coletânea instigante. E que os deuses acudam. 